\title{
PEMANFAATAN KULIT PISANG AMBON (Musa Paradisiaca) MENJADI OLAHAN DODOL BERNILAI JUAL TINGGI
}

\section{IMPLEMENTATION OF AMBON BANANA (Musa paradisiaca) HUSK TURN INTO HIGH ADDED VALUE OF DODOL}

\author{
Syaradina Nafisa Aftori ${ }^{1}$, Bayu Adirianto ${ }^{1}$, Fahrezi Finandiki Pardani ${ }^{2}$, Ridwan \\ Nuraripin ${ }^{2}$
}

\author{
${ }^{1}$ Program Studi Agribisnis Hortikultura, Jurusan Pertanian, \\ Politeknik Pembangunan Pertanian (POLBANGTAN) Bogor. \\ JI Aria Surialaga No. 1. Bogor, Jawa Barat. \\ ${ }^{2}$ Program Studi Penyuluhan Pertanian Berkelanjutan, Jurusan Pertanian, \\ Politeknik Pembangunan Pertanian (POLBANGTAN) Bogor. \\ JI Aria Surialaga No. 1. Bogor, Jawa Barat. \\ *Korespondensi penulis, Email: bavuadirianto@gmail.com
}

\begin{abstract}
In Indonesia, the orientation of banana processing is only focused on fruit processing so that the amount of banana peels is usually discarded because it is considered as waste, which results in inefficient production. whereas the peel has a nutritional content. This study aims to make banana peel waste can be used as dodol which is preferred by panelists, analyze the feasibility of banana peel dodol business and sensory characteristics of banana peel dodol. The method used in this study is a direct experiment of making dodol with a ratio of banana peel and glutinous rice flour which is 1: 1, analyzing business feasibility and SWOT identification, as well as conducting organoleptic and hedonic sensory tests. The results showed that banana peel has the potential to be processed as dodol without reducing the characteristics of dodol based on SNI, the business feasibility analysis shows the $R$ / C ratio of dodol products has a value of 1.3, which means the business of banana peel dodol is feasible to be developed. Organoleptic sensory test results showed that dodol was brown, bananascented, chewy-textured, and banana-flavored. Sensory testing of dodol selected hedonically has the highest level of preference by panelists.
\end{abstract}

Keywords: Banana, food waste, dodol.

\section{ABSTRAK}

Di Indonesia, orientasi pengolahan pisang hanya terfokus pada pengolahan buah sehingga jumlah kulit pisang biasanya dibuang karena dianggap sebagai sampah, hal tersebut mengakibatkan ketidakefisienan produksi, padahal kulitnya memiliki 
kandungan gizi. Penelitian ini bertujuan untuk membuat limbah kulit pisang dapat dijadikan dodol yang disukai panelis, menganalisis kelayakan usaha dodol kulit pisang dan karakteristik sensori dodol kulit pisang. Metode yang digunakan dalam penelitian ini yaitu eksperimen langsung pembuatan dodol dengan perbandingan kulit pisang dan tepung beras ketan yaitu 1:1, menganalisa kelayakan usaha dan identifikasi SWOT, serta melakukan uji sensori secara organoleptik dan hedonik. Hasil penelitian menunjukkan bahwa kulit pisang berpotensi dijadikan olahan dodol tanpa mengurangi karakteristik dodol berdasarkan SNI, analisa kelayakan usaha menunjukan rasio $\mathrm{R} / \mathrm{C}$ produk dodol bernilai 1,3 yang berarti usaha dodol kulit pisang layak untuk dikembangkan. Hasil pengujian sensori secara organoleptik menunjukkan bahwa dodol berwarna coklat, beraroma pisang, bertekstur kenyal, dan berasa pisang. Pengujian sensori dodol terpilih secara hedonik memiliki tingkat kesukaan tertinggi oleh panelis.

Kata kunci: Pisang, food waste, dodol.

PENDAHULUAN

\section{Latar Belakang}

Pisang merupakan tanaman tropis yang banyak dibudidayakan di Indonesia. Produksi buah pisang menduduki peringkat pertama hasil pertanian di Indonesia. Berdasarkan Pusat Kajian Hortikultura Tropika (2014) bahwa data nilai ekspor pisang semakin meningkat dari tahun 2012 sebesar 1,49 juta ton menjadi 2,33 juta ton pada tahun 2013. Produktivitas pisang yang tinggi dan tergolong jenis buah yang mudah rusak, sehingga mendorong pemanfaatan buah pisang yang besar untuk berbagai jenis makanan. Hal tersebut akan menghasilkan limbah kulit pisang dengan volume yang besar. Bobot kulit pisang didapat dari 40\% buahnya kilogram dari konsumsi pisang nasional.

Pengolahan buah pisang pada akhir proses pengolahannya selain terdapat limbah buangan berupa kulit pisang, terdapat pula tandan pisang serta bonggol pisang. Kulit pisang merupakan bahan buangan (limbah buah pisang) yang cukup banyak jumlahnya dan belum dimanfaatkan secara nyata, Limbah kulit pisang selama ini hanya dibuat sebagai pakan ternak, padahal kulit pisang mengandung komponen berupa pektin berkisar antara 0,9\% dari berat kering (Hanum, 2012). Pektin banyak terdapat pada bahan limbah hasil pertanian seperti kulit buah. Selain pektin, kulit pisang juga mengandung karbohidrat 
$59 \%$ dan serat kasar 31,7\% (Anhwange et al., 2009).

Melihat kandungan gizi yang cukup lengkap dan kandungan serat kasar yang cukup tinggi, kulit pisang dapat dimanfaatkan sebagai produk makanan kaya akan serat. Serat mempunyai peranan penting pada proses pencernaan makanan dalam tubuh dan memiliki sifat mengenyangkan. Salah satu upaya pemanfaatan kulit pisang adalah dengan dijadikannya sebagai bahan tambahan yang disubtitusikan dengan tepung ketan pada pembuatan dodol. Dodol merupakan produk olahan hasil pertanian yang termasuk dalam jenis pangan semi basah bertekstur kenyal dan memiliki cita rasa manis sehingga dapat langsung dimakan. Bahan utama yang digunakan dalam pembuatan dodol adalah tepung ketan putih, gula dan santan kelapa (SNI 01- 29862013).

Dodol dibedakan menjadi dua macam, yaitu berdasarkan buah yang ditambahkan dan berdasarkan tempat pengolahannya. Jenis dodol berdasarkan buah yang ditambahkan misalnya dodol nanas dan dodol durian, sedangkan jenis dodol berdasarkan tempat pengolahan yaitu dodol garut (Borsak Manogar dkk,
2017). Pengolahan dodol menggunakan kulit pisang ambon yang disubstitusikan dengan bahan baku tepung ketan diharapkan dapat menjadi olahan inovasi kaya akan serat pangan, dapat mengurangi limbah kulit pisang yang ketersediaanya cukup melimpah dan meningkatkan nilai jual produk dodol.

\section{METODE}

$\begin{array}{ll}\text { Penelitian dilakukan di } & \text { daboratorium Pasca Panen }\end{array}$

Polbangtan Bogor Kampus Cibalagung selama satu hari pada selasa, 12 November 2019. Adapun alat yang diperlukan dalam pembuatan dodol kulit pisang yaitu wajan besar, pisau, sudip, timnbangan digital, plastik PP, kemasan box, loyang $20 \mathrm{~cm} \times 20 \mathrm{~cm}$, food processor, talenan, baskom plastik, dan panci kukus. Bahan yang digunakan antara lain: gula pasir, gula merah, tepung beras ketan, margarin, pisang ambon, dan santan.

Tahapan pembuatan dodol ini diawali oleh persiapan bahan sesuai formulasi, kemudian pencucian dengan air mengalir, lalu streaming (kulit pisang bersih di kukus selama 15 menit untuk mengaktifkan flavor dan mempermudah proses selanjutnya, selanjutnya tahap penghancuran 
sampai menjadi pure. Setelah itu, pencampuran bahan-bahan kedalam wajan dan dipanaskan pada suhu $80^{\circ} \mathrm{C}$ selama 3 jam hingga menjadi liat. Lalu, dodol didinginkan diatas loyang selama 30 menit dan selanjutnya ditimbang dan dikemas.

Analisis yang dilakukan adalah identifikasi peluang pengembangan produk, analisis usaha, uji organoleptik dan uji hedonik. Penelitian dilakukan secara eksperimental dengan melakukan uji hedonik kepada responden untuk menilai sangat suka, suka, agak suka dan tidak suka. Responden penelitian adalah mahasiswa Polbangtan Bogor sebanyak 20 orang. Responden diminta mencoba dodol dan memberikan penilaian sebagai disajikan pada Tabel 1. Nilai tertinggi menunjukkan kriteria yang disukai oleh responden, paling layak dikonsumsi dan dipasarkan. Data yang diperoleh direkap dan dianalisis secara deskriptif.

Tabel 1. Uji Sensori secara Hedonik

\begin{tabular}{|l|l|}
\hline Skala Hedonik & Skala Numerik \\
\hline Sangat suka & 1 \\
\hline Suka & 2 \\
\hline Agak suka & 3 \\
\hline Tidak suka & 4 \\
\hline
\end{tabular}

Uji organoleptik menggunakan metode uji deskriptif. Tujuan uji ini adalah memberikan gambaran keseluruhan atribut mutu dari suatu komoditi dalam bentuk grafik majemuk serta gambaran perbandingannya dengan suatu standar. Tahapan uji ini adalah tentukan terlebih dahulu atribut mutu yang hendak dianalisis, yang dalam hal ini dapat berupa warna, rasa, aroma, dan tekstur. Kemudian, produk disajikan kepada panelis dan dipahami keseluruhan atribus mutu. Selanjutnya panelis mengisi lembar isian yang disediakan. Berikut Tabel 2 menjelaskan atribut mutu untuk uji organoleptik.

Table 2. Uji organoleptik dodol kulit pisang

\begin{tabular}{|l|l|l|l|}
\hline $\begin{array}{l}\text { Nama } \\
\text { sampel }\end{array}$ & \multicolumn{3}{|c|}{ : Dodol kulit pisang } \\
\hline $\begin{array}{l}\text { Atribut } \\
\text { Mutu }\end{array}$ & \multicolumn{3}{|c|}{ Kategori } \\
\hline Warna & Hitam & Coklat & Merah \\
\hline Rasa & $\begin{array}{l}\text { Khas } \\
\text { pisang }\end{array}$ & $\begin{array}{l}\text { khas } \\
\text { dodol }\end{array}$ & $\begin{array}{l}\text { Tidak } \\
\text { khas }\end{array}$ \\
\hline
\end{tabular}




\begin{tabular}{|l|l|l|l|}
\hline Aroma & $\begin{array}{l}\text { khas } \\
\text { pisang }\end{array}$ & $\begin{array}{l}\text { khas } \\
\text { dodol }\end{array}$ & $\begin{array}{l}\text { Tidak } \\
\text { khas }\end{array}$ \\
\hline Tekstur & Keras & Kenyal & Lembut \\
\hline
\end{tabular}

\section{HASIL DAN PEMBAHASAN}

Berdasarkan identifikasi SWOT pada usaha dodol pisang ini, kekuatan (strength) produk ini adalah produk tahan lama, tidak menggunakan pemanis dan pengawet buatan, praktis dan fleksibel, ramah lingkungan, inovatif dan memiliki rasa khas. Kemudian, peluang (opprotunities) produk ini adalah bahan baku mudah didapat, produk menarik, permintaan meningkat, dan unik. Sedangkan kelemahan (weakness) produk ini adalah kemasan masih sederhana dan konvensional. Selain itu, ancaman (threat) produk ini adalah munculnya kompetitor yang memasarkan produk baru. Identifikasi peluang pengembangan produk ini dapat dilihat pada Tabel 3.

Tabel 3. Identifikasi peluang pengembangan dodol pisang

\begin{tabular}{|r|l|}
\hline $\begin{array}{l}\text { Faktor } \\
\text { Eksternal }\end{array}$ & $\begin{array}{l}\text { Faktor Internal : } \\
\text { Kekuatan (s) }\end{array}$ \\
\hline $\begin{array}{r}\text { Peluang } \\
\text { (o) }\end{array}$ & $\begin{array}{l}\text { Produk tahan lama, tidak } \\
\text { menggunakan pemanis } \\
\text { dan pengawet buatan, }\end{array}$ \\
\hline
\end{tabular}

\begin{tabular}{|c|c|}
\hline & $\begin{array}{l}\text { praktis dan fleksibel, } \\
\text { ramah lingkungan, } \\
\text { memiliki rasa khas, } \\
\text { bahan baku mudah } \\
\text { didapat, produk menarik, } \\
\text { permintaan meningkat }\end{array}$ \\
\hline $\begin{array}{r}\text { Ancaman } \\
(\mathrm{t})\end{array}$ & $\begin{array}{l}\text { Produk tahan lama, tidak } \\
\text { menggunakan pemanis } \\
\text { dan pengawet buatan, } \\
\text { praktis dan fleksibel, } \\
\text { ramah lingkungan, } \\
\text { memiliki rasa khas, } \\
\text { munculnya kompetitor } \\
\text { yang memasarkan } \\
\text { produk baru }\end{array}$ \\
\hline $\begin{array}{l}\text { Faktor } \\
\text { Eksternal }\end{array}$ & $\begin{array}{l}\text { Faktor Internal : } \\
\text { Kelemahan (w) }\end{array}$ \\
\hline $\begin{array}{r}\text { Peluang } \\
\text { (0) }\end{array}$ & $\begin{array}{l}\text { Bahan baku mudah } \\
\text { didapat, produk menarik, } \\
\text { permintaan meningkat, } \\
\text { kemasan } \\
\text { sederhana } \\
\text { konvensional }\end{array}$ \\
\hline $\begin{array}{r}\text { Ancaman } \\
(\mathrm{t})\end{array}$ & $\begin{array}{lr}\text { Kemasan } & \text { masih } \\
\text { sederhana } & \text { dan } \\
\text { konvensional, munculnya } \\
\text { kompetitor } \\
\text { memasarkan } \\
\text { baru }\end{array}$ \\
\hline \multicolumn{2}{|c|}{ Penilaian dengan indera } \\
\hline
\end{tabular}


digunakan. Hasil karakterisasi produk dodol secara organoleptik adalah tekstur produk kenyal, warna coklat, aroma dodol khas pisang, rasa dodol khas pisang. Hasil karakteristik tersebut sudah sesuai dengan syarat mutu SNI dodol No.01-2986-2013

Uji hedonik kepada 20 responden adalah sebanyak 18 responden menilai sangat suka dan 2 orang menilai suka seperti yang disajikan pada Tabel 4. Respon terhadap produk dodol pisang ini menunjukkan tingkat penerimaan konsumen sangat tinggi karena sebanyak $90 \%$ menyatakan sangat suka produk ini.

Tabel 4. Hasil uji hedonik terhadap dodol pisang.

\begin{tabular}{|l|l|l|}
\hline $\begin{array}{l}\text { Skala } \\
\text { Hedonik }\end{array}$ & $\begin{array}{l}\text { Jumlah } \\
\text { (responden) }\end{array}$ & $\begin{array}{l}\text { Presentase } \\
(\%)\end{array}$ \\
\hline $\begin{array}{l}\text { Sangat } \\
\text { suka }\end{array}$ & 18 & 90 \\
\hline Suka & 2 & 10 \\
\hline $\begin{array}{l}\text { Agak } \\
\text { suka }\end{array}$ & 0 & 0 \\
\hline $\begin{array}{l}\text { Tidak } \\
\text { suka }\end{array}$ & 0 & 0 \\
\hline \multicolumn{2}{|c|}{ Berdasarkan analisa usaha } \\
\hline
\end{tabular}

pembuatan dodol pisang pada Tabel 5 dapat diketahui nilai BEP untuk harga produksi (Rp. 183.543) lebih kecil dari nilai penerimaan (Rp. 350.000) sehingga telah melewati titik impas biaya-biaya yang telah dikeluarkan untuk produksinya. BEP merupakan suatu kondisi pada saat penerimaan yang diperoleh sama dengan modal yang dikeluarkan. Berdasarkan analisis BEP produksi dodol pisang maka dapat dikatakan usaha ini layak dilanjutkan.

Tabel 5. Hasil analisa usaha pembuatan dodol pisang

\begin{tabular}{|c|c|c|}
\hline No. & Jenis analisis & Nilai \\
\hline 1 & $\begin{array}{ll}\text { Biaya } & \text { Tetap } \\
(F C) & \end{array}$ & Rp.171.625 \\
\hline 2 & $\begin{array}{l}\text { Biaya Variabel } \\
\text { (VC) }\end{array}$ & Rp.87.000 \\
\hline 3 & $\begin{array}{l}\text { Biaya } \\
\text { Penyusutan }\end{array}$ & Rp.6.607 \\
\hline 4 & Biaya Total & Rp.265.232 \\
\hline 5 & $\begin{array}{l}\text { Harga Pokok } \\
\text { Produksi (HPP) }\end{array}$ & Rp.13.261 \\
\hline 6 & Harga & Rp.17.500 \\
\hline 7 & Penerimaan & Rp.350.000 \\
\hline 8 & $\begin{array}{l}\text { Break Even } \\
\text { Point } \\
\text { (BEP)/Titik } \\
\text { Impas (Rp) }\end{array}$ & Rp.183.543 \\
\hline 9 & $\begin{array}{l}\text { Break Even } \\
\text { Point } \\
\text { (BEP)/Titik } \\
\text { Impas }\end{array}$ & 11 buah \\
\hline
\end{tabular}




\begin{tabular}{|l|l|l|}
\hline & $\begin{array}{l}\text { (kuantitas } \\
\text { produk) }\end{array}$ & Rp.84.677 \\
\hline 10 & Laba & $\begin{array}{l}31,92 \% \\
\text { (presentase) }\end{array}$ \\
\hline 11 & Rasio R/C & 1,31 \\
\hline 13 & Rasio B/C & 0,3 \\
\hline
\end{tabular}

Dalam penelitian ini, nilai rasio $\mathrm{R} / \mathrm{C}$ yaitu sebesar 1,31 yang diperoleh dari pembagian penerimaan atas biaya. Sehingga dapat dikatakan usaha dodol pisang layak untuk dijalankan dan mempunyai prospek yang baik karena memiliki rasio $\mathrm{R} / \mathrm{C}$ yang lebih dari 1 (rasio $R / C>1$ ). Selain itu, nilai rasio $\mathrm{B} / \mathrm{C}$ sebesar 0,3 sehingga memenuhi syarat usaha karena nilai laba lebih dari 0 (rasio $B / C>0)$. Dari hasil anlalisis usaha tersebut dapat disimpulkan bahwa usaha ini layak dilanjutkan karena perhitungan kelayakan pada aspek finansial telah memenuhi syarat terhadap kriteria kelayakan diantaranya BEP, Rasio R/C, dan Rasio B/C.

\section{KESIMPULAN}

Dari pembahasan diatas dapat ditarik beberapa kesimpulan yaitu:
1. Kulit pisang ambon berpotensi dijadikan dodol tanpa mengurangi karakteristik mutu dodol berdasarkan SNI No.012986-2013.

2. Hasil pengujian sensori secara organoleptik menunjukan dodol yang kami buat mempunyai warna coklat, beraroma pisang, bertekstur kenyal, dan berasa pisang, sedangkan untuk pengujian sensori dodol secara hedonik memiliki rata-rata tingkat kesukaan tertinggi oleh panelis.

3. Analisa kelayakan usaha produk dodol memiliki nilai rasio $\mathrm{R} / \mathrm{C}$ 1,31 dan rasio $\mathrm{B} / \mathrm{C}$ 0,3 yang berarti usaha dodol kulit pisang ini layak untuk dikembangkan.

\section{Saran}

Diperlukan penelitian lanjutan mengenai lama masa simpan dodol dengan penambahan kulit pisang ambon.

\section{DAFTAR PUSTAKA}

Anhwange, BA., TJ. Ugye, TD. Nyiaatagher. 2009. Chemical composition of Musa sapientum (Banana) peels. EJEAFChe 8 (6): 437-442.

Hanum, F., Tarigan, M. A., dan Kaban, I. M. D. 2012. Ekstraksi Pektin dari 
Kulit Buah Pisang Kepok (Musa

Paradisiaca). Jurnal Teknik Kimia

USU, 1(1), 49-53.

Manogar, B., Pato, U., dan Ayu, D. F. 2017. Karakteristik Mutu Dodol Ketan dengan Penambahan Pisang Ambon dan Jambu Biji. Jurnal Online Mahasiswa Fakultas Pertanian Universitas Riau, 4(2), 1-11.

[PKHT] Pusat Kajian Hortikultura Tropika. 2014. Nilai ekspor pisang Indonesia.http://pkht.Deptan.go.id. (18 November 2019).

Ranita, S. V., dan Hanum, Z. 2018. Revenue Cost dan Analisis Swot dalam Pengembangan Usaha. Jurnal Bis-A: Jurnal Bisnis Administrasi, 5(2), 14-19.

[SNI] Standar Nasional Indonesia. 2013. Dodol Beras Ketan. SNI2986:2013. Badan Standarisasi Nasional. Jakarta. $45 \mathrm{hlm}$. Yuliza, M. dan Basri, S. 2018. Marketing Strategy of Dodol Singkong Malayan. Jurnal Apresiasi Ekonomi, 6(3), 253-261. 